\title{
Kinerja Bioreaktor Hibrid Anaerob dengan Media Batu untuk Pengolahan Air Buangan yang Mengandung Molase
}

\author{
Mindriany Syafila, Asis H. Djajadiningrat \\ Marisa Handajani \\ Departemen Teknik Lingkungan, Institut Teknologi Bandung, \\ Jl. Ganesa 10 Bandung 40132, Indonesia \\ Tel. 022 - 2502647, Fax. 022 - 2530704, \\ e-mail address : eureka97@bdg.centrin.net.id
}

\begin{abstract}
Abstrak. Bioreaktor hibrid anaerob merupakan penggabungan antara sistem pertumbuhan tersuspensi dan pertumbuhan terlekat. Dalam penelitian ini media pelekatan mikroorganisma yang digunakan adalah batu. Larutan umpan dibuat dari molase yang diencerkan sebagai salah satu contoh air buangan dengan beban organik tinggi. Proses degradasi dilakukan dengan waktu detensi hidrolis 30 jam dan rasio tinggi bagian tersuspensi dan terlekat sebesar 1:2. Bioreaktor dioperasikan pada variasi konsentrasi organik 10.000, 20.000, 30.000 dan 40.000 mg/L COD. Hasil penelitian menunjukkan bahwa peningkatan konsentrasi organik mempengaruhi kinerja bioreaktor dan produksi metan sebagai hasil proses anaerob belum optimal.
\end{abstract}

Abstract. Anaerobic hybrid bioreactor is a combination of suspended and attached growth systems. Stone was used as the microorganism attachment media. The feeding solution was made from molasses diluted to COD concentration of $10,000,20,000,30,000$ and $40,000 \mathrm{mg} / \mathrm{L}$. The hydraulic detention time was 30 hours and the height ratio between suspended and attached growth system was 0.5 . The result shows that the organic concentration seems to be on of the determining factors. Furthermore, since the methane production was still low enough, it seems that the process has not achieved its optimum condition for methanogenic stage.

Kata kunci : Anaerob, batu, hybrid, molase, organic 


\section{Pendahuluan}

Bahan organik tinggi yang terkandung dalam air buangan berpotensi untuk mencemari lingkungan alam sekitarnya. Pengolahan secara biologi merupakan salah satu alternatif usaha untuk menanggulanginya. Bahan organik tinggi (COD $>4.000 \mathrm{mg} / \mathrm{L}$ ) lebih tepat diolah dengan menggunakan pengolahan biologi secara anaerob [1]. Pengolahan biologi secara anaerob memiliki beberapa kelebihan diantaranya :

a) tidak membutuhkan energi untuk aerasi, sehingga kemampuan pembebanan bahan organik lebih tinggi karena tidak dibatasi oleh kebutuhan oksigen. Sebagai perbandingan untuk pengolahan aerob diperlukan energi untuk mentransfer oksigen sekitar $500-2.000 \mathrm{kwh}$ per $1.000 \mathrm{~kg}$ COD yang diolah [2].

b) gas metan yang merupakan produk akhir dapat menjadi sumber energi. Proses anaerob menghasilkan $12 \times 10^{6} \mathrm{BTU} \mathrm{CH}_{4}$ per $1.000 \mathrm{~kg} \mathrm{COD}$ [2].

c) kelebihan biomassa yang terbentuk dan harus dibuang hanya $10 \%$ dibandingkan dengan lumpur yang dihasilkan dalam proses aerob, yang berarti bahwa biaya pengolahan lumpur akan lebih rendah.

Salah satu modifikasi dalam proses pengolahan anaerob dilakukan dengan menggabungkan pertumbuhan biomassa terlekat dan tersuspensi di dalam satu bioreaktor yang disebut sebagai reaktor hibrid. Desain ini memiliki kelebihan dalam mempertahankan konsentrasi biomassa dengan jumlah yang tinggi di dalam reaktor sehingga diharapkan dapat meningkatkan efisiensi pengolahan air buangan dengan konsentrasi organik tinggi. Tabel 1 memperlihatkan perbandingan kinerja antara bioreaktor tersuspensi, terlekat dan hibrid.

Reaktor hibrid merupakan kombinasi reaktor pertumbuhan terlekat di bagian bawah dengan pertumbuhan tersuspensi di bagian atasnya. Kinerja yang baik dari desain tergantung pada kapasitas media untuk metan biomassa, sekaligus sebagai tempat mikroorganisma beraktivitas. Media untuk reaktor anaerob sebaiknya memiliki berat jenis yang rendah dan porositas yang besar untuk menurunkan gaya statis pada bagian bawah reaktor dan untuk menghindari penyumbatan. Pemasangan media secara acak lebih disukai untuk model aliran ke atas karena biaya instalasi lebih rendah karena jumlah padatan tersuspensi yang ditahan lebih besar dalam lapisan media tersebut [3]. 


\begin{tabular}{|c|c|c|c|}
\hline Faktor & Tersuspensi & Hibrid & Terlekat \\
\hline Biomassa yang dicapai & Rendah & Tinggi & Tinggi \\
\hline $\begin{array}{l}\text { Sludge Retention Time } \\
\text { (SRT) yang dapat dicapai }\end{array}$ & Rendah & Tinggi & Tinggi \\
\hline $\begin{array}{l}\text { Kesesuaian untuk air } \\
\text { buangan dengan partikulat }\end{array}$ & $\mathrm{Ya}$ & $\begin{array}{c}\text { Penyisihan } \\
\text { sebagian }\end{array}$ & Penyisihan kecil \\
\hline $\begin{array}{l}\text { Kesesuaian untuk air } \\
\text { buangan konsentrat }\end{array}$ & Ya & Tidak & Tidak \\
\hline $\begin{array}{l}\text { Kesesuaian untuk air } \\
\text { buangan encer }\end{array}$ & Tidak & Ya & Ya \\
\hline Efisiensi penyisihan & Terbatas & Tinggi & Tinggi \\
\hline $\begin{array}{l}\text { Retensi terhadap kondisi } \\
\text { toksik dan dinamika } \\
\text { operasi }\end{array}$ & $\begin{array}{c}\text { Terbatas pada } \\
\text { Sludge Retention } \\
\text { Time (SRT) } \\
\text { pendek } \\
\end{array}$ & $\begin{array}{l}\text { Sludge Retention } \\
\text { Time (SRT) } \\
\text { panjang stabilitas } \\
\text { meningkat } \\
\end{array}$ & $\begin{array}{l}\text { Sludge Retention } \\
\text { Time (SRT) } \\
\text { panjang stabilitas } \\
\text { meningkat } \\
\end{array}$ \\
\hline $\begin{array}{l}\text { Mempertahankan } \\
\text { integritas hidrolis }\end{array}$ & $\begin{array}{c}\text { Relatif sederhana } \\
\text { dengan } \\
\text { pengadukan } \\
\text { mekanis } \\
\end{array}$ & $\begin{array}{c}\text { Baik dengan } \\
\text { resirkulasi efluen } \\
\text { dan pengadukan } \\
\text { biogas }\end{array}$ & $\begin{array}{l}\text { Akumulasi biogas } \\
\text { berpengaruh } \\
\text { terhadap hidrolis } \\
\text { reactor }\end{array}$ \\
\hline Kebutuhan energi & Paling rendah & $\begin{array}{l}\text { Tinggi bila ada } \\
\text { resirkulasi }\end{array}$ & $\begin{array}{l}\text { Tinggi jika media } \\
\text { terfluidisasi }\end{array}$ \\
\hline
\end{tabular}

Sumber [4]

Tabel 1. Perbandingan sistem pengolahan anaerob tersuspensi, hibrid dan terlekat

Dalam penelitian ini media pendukung pertumbuhan biomassa yang digunakan adalah batu. Batu dipilih karena batu relatif murah, kuat, mudah didapat dan dianggap cukup baik sebagai media melekatnya mikroorganisma.

Hasil penelitian pendahuluan terhadap bioreaktor upflow hibrid anaerob menggunakan media bambu, plastik dan batu untuk mengolah glukosa beban tinggi memberikan hasil terbaik pada media bambu. Selain itu diperoleh waktu detensi optimum $60.000 \mathrm{mg} / \mathrm{L}$ dan variasi rasio tinggi fasa terlekat dengan fasa tersuspensi $1: 1$.

Variasi rasio ketinggian sistem terlekat terhadap ketinggian sistem tersuspensi akan mempengaruhi efisiensi penyisihan senyawa organik sebagai substrat. Penggunaan bioreaktor hibrid dengan kombinasi 1/3 bagian merupakan sistem tersuspensi dan $2 / 3$ bagian merupakan sistem terlekat menghasilkan efisiensi penyisihan substrat sebesar 80\% [2]. Hal ini dikarenakan proses metanogenesa yang diharapkan terjadi pada sistem 
terlekat, memerlukan waktu yang lebih lama dibandingkan dengan proses asidogenesa yang terjadi pada sistem tersuspensi.

Penelitian diharapkan menghasilkan parameter kinetika proses penyisihan bahan organik konsentrasi tinggi dalam bioreaktor upflow hibrid anaerob yang dapat digunakan sebagai pengetahuan dasar dalam desain teknik bioreaktor untuk pengolahan air buangan yang mengandung bahan organik tinggi.

\section{Bahan dan Metoda}

Reaktor Skala Laboratorium

Instalasi pengolah air buangan yang digunakan terdiri dari peralatan utama dan peralatan pendukung dengan skema seperti pada Gambar 1.

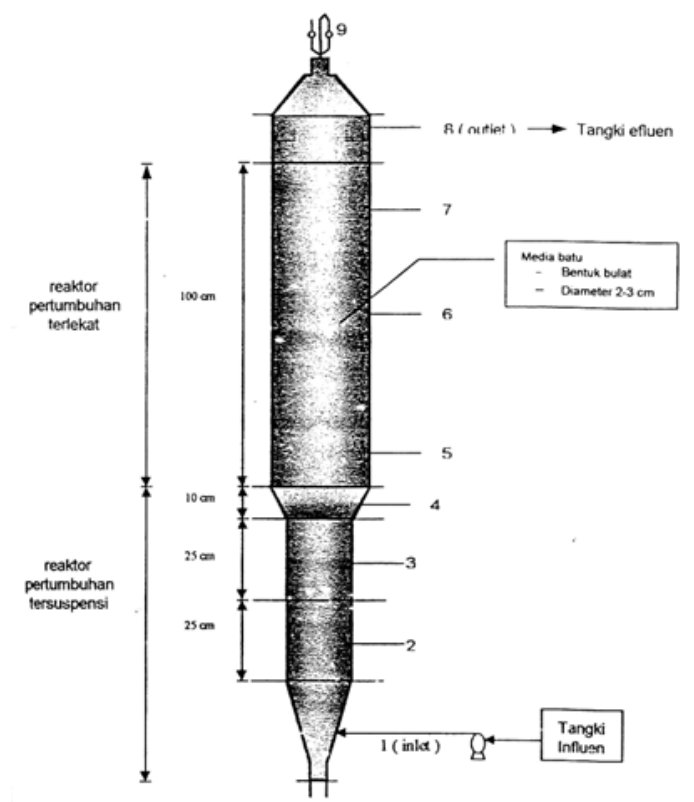

Gambar 1. Skema bioreaktor hibrid anaerob skala laboratorium

\section{Keterangan :}

$1 \quad$ : titik inlet

2,3 : titik sampling sistem tersuspensi

4 : titik sampling di akhir sistem tersuspensi dan awal sistem terlekat

$5,6,7$ : titik sampling cairan sistem terlekat

$8 \quad$ : titik outlet

$9 \quad$ : titik sampling gas 


\section{Pembibitan dan Aklimatisasi}

Seeding dan aklimatisasi dilakukan untuk mengembangbiakkan dan mengadaptasikan mikroorganisma anaerob dengan cairan influen yang akan diolah. Bibit diambil dari rumen sapi. Seeding dilakukan secara batch dalam tangki dengan memberikan substrat glukosa, nutrien, trace mineral dan untuk mengusir oksigen digunakan gas $\mathrm{N}_{2}$.

Komposisi nutrien dan trace mineral diberikan sehingga memenuhi perbandingan COD:N:P = 400:7:1. Setelah jumlah bakteri cukup (VSS > 5.000 $\mathrm{mg} / \mathrm{L})$ dilakukan aklimatisasi. Tahap aklimatisasi dilakukan secara batch dengan peningkatan kosentrasi molase. Pada saat keseluruhan air buangan sudah merupakan air buangan yang mengandung molase (tanpa glukosa), mikroorganisma dimasukkan ke dalam reaktor dan substrat molase dialirkan secara kontinu. Tahap ini dilakukan sampai terbentuk biofilm pada media dan konsentrasi biomassa sudah cukup.

\section{Karakteristik Air Buangan}

Dalam penelitian ini digunakan air buangan molase yang diencerkan untuk mendapatkan konsentrasi 10.000, 20.000, 30.000 dan $40.000 \mathrm{mg} / \mathrm{L}$ COD. Molase yang digunakan berasal dari pabrik gula tebu PT Karang Suwung, Cirebon, dengan karakteristik seperti pada Tabel 2.

\begin{tabular}{|l|c|l|c|}
\hline Parameter & Konsentrasi (ppm) & Parameter & Konsentrasi (ppm) \\
\hline $\mathrm{COD}$ & $285.200-1.668 .000$ & $\mathrm{Cu}^{2+}$ & $3,2-5,12$ \\
\hline $\mathrm{N}$ & 2.510 & $\mathrm{Fe}^{2+}$ & $60-291,07$ \\
\hline $\mathrm{P}$ & 385 & $\mathrm{Mn}^{2+}$ & $8,4-18,63$ \\
\hline $\mathrm{SO}_{4}^{2-}$ & 25.100 & $\mathrm{~K}^{+}$ & $11.600-18.080$ \\
\hline $\mathrm{PO}_{4}^{3-}$ & $444-654$ & $\mathrm{Na}^{+}$ & $134-200$ \\
\hline $\mathrm{Cl}^{-}$ & 34.100 & $\mathrm{Ca}^{2+}$ & $7.400-9.840$ \\
\hline $\mathrm{Zn}{ }^{2+}$ & $5,4-8,03$ & $\mathrm{Mg}^{2+}$ & $860-1.800$ \\
\hline $\mathrm{B}$ & 2,1 & $\mathrm{Cr}^{2+}$ & Tidak terdeteksi \\
\hline Gula tereduksi & $12,08 \%$ & $\mathrm{Cd}$ & Tidak terdeteksi \\
\hline Disakarida & $17,62 \%$ & $\mathrm{~Pb}$ & Tidak terdeteksi \\
\hline
\end{tabular}

Tabel 2. Karakteristik air buangan yang mengandung molase

Pada penelitian ini analisa kimiawi sampel ditekankan pada karakteristik COD. Selain itu juga dilakukan analisa terhadap kandungan glukosa, total asam volatil (TAV) dan gas metan sebagai produk biodegradasi. 


\section{Hasil dan Pembahasan}

\section{Konsentrasi COD, Total Asam Volatil (TAV) dan Glukosa}

Untuk melihat pengaruh variasi konsentrasi organik pada tahapan proses yang berlangsung dalam bioreaktor hibrid anaerob dilakukan penelitian dengan 4 variasi konsentrasi, yaitu 10.000, 20.000, 30.000 dan $40.000 \mathrm{mg} / \mathrm{L}$ COD dengan waktu detensi hidrolis 30 jam. Hasil yang diperoleh dari pengukuran COD, TAV dan glukosa pada 4 titik sampling disajikan pada Gambar 2 sampai Gambar 5.

Hasil pengukuran parameter COD menunjukkan bahwa secara umum terjadi penurunan COD dari influen. Penurunan ini berlangsung pada bagian pertumbuhan tersuspensi dan pertumbuhan terlekat. Penyisihan COD untuk 4 variasi konsentrasi $10.000,20.000,30.000$ dan $40.000 \mathrm{mg} / \mathrm{L}$ adalah $55 \%$, $17 \%, 14 \%$ dan $9 \%$. Hasil ini berbeda dengan yang diperoleh pada konsentrasi $10.000 \mathrm{mg} / \mathrm{L}$ COD dimana 54\% penyisihan COD terjadi pada bagian tersuspensi, sedangkan kontribusi bagian terlekat hanya $1 \%$.

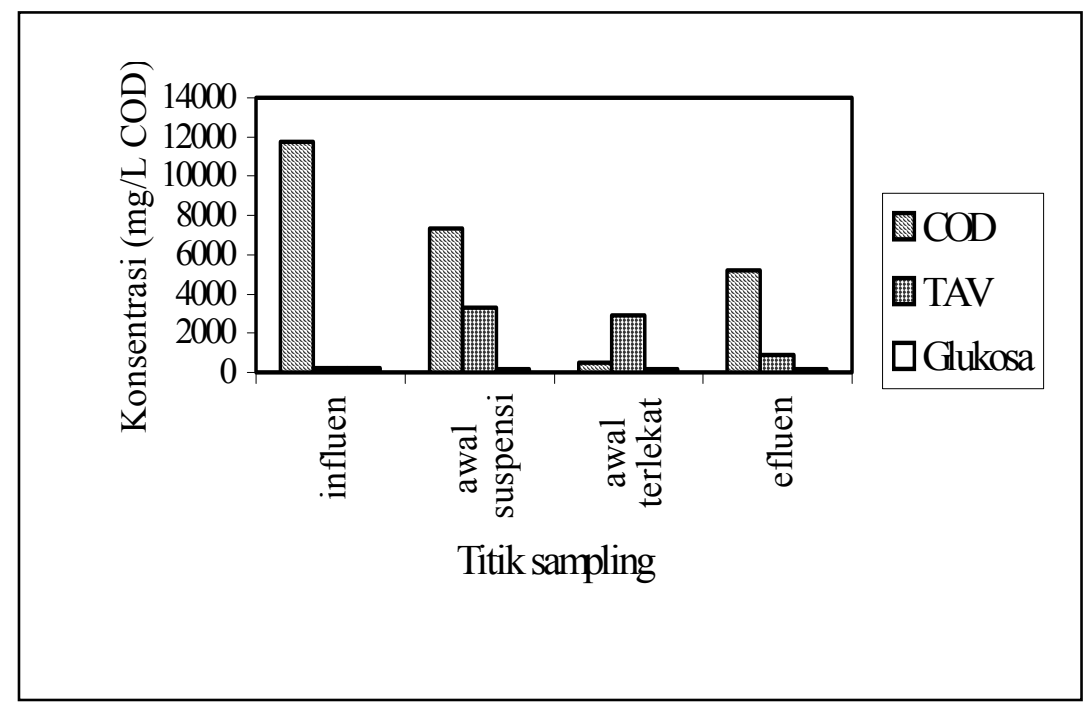

Gambar 2. Konsentrasi COD, TAV dan Glukosa dalam bioreaktor hibrid pada konsentrasi $10.000 \mathrm{mg} / \mathrm{L}$ COD 


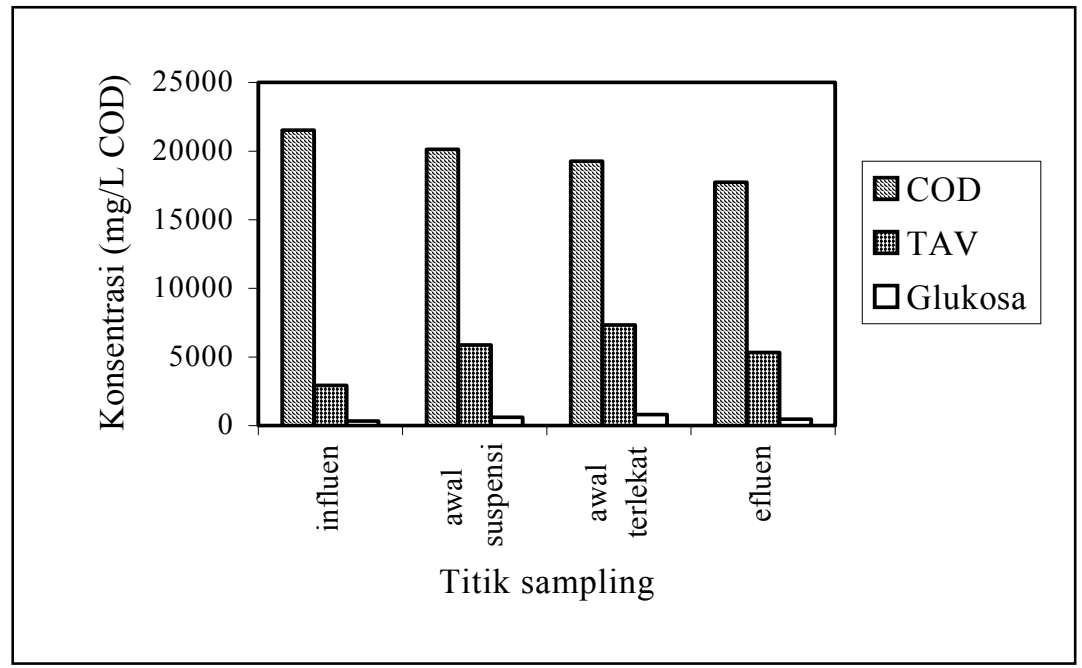

Gambar 3. Konsentrasi COD, TAV dan Glukosa dalam bioreaktor hibrid pada konsentrasi $20.000 \mathrm{mg} / \mathrm{L} \mathrm{COD}$

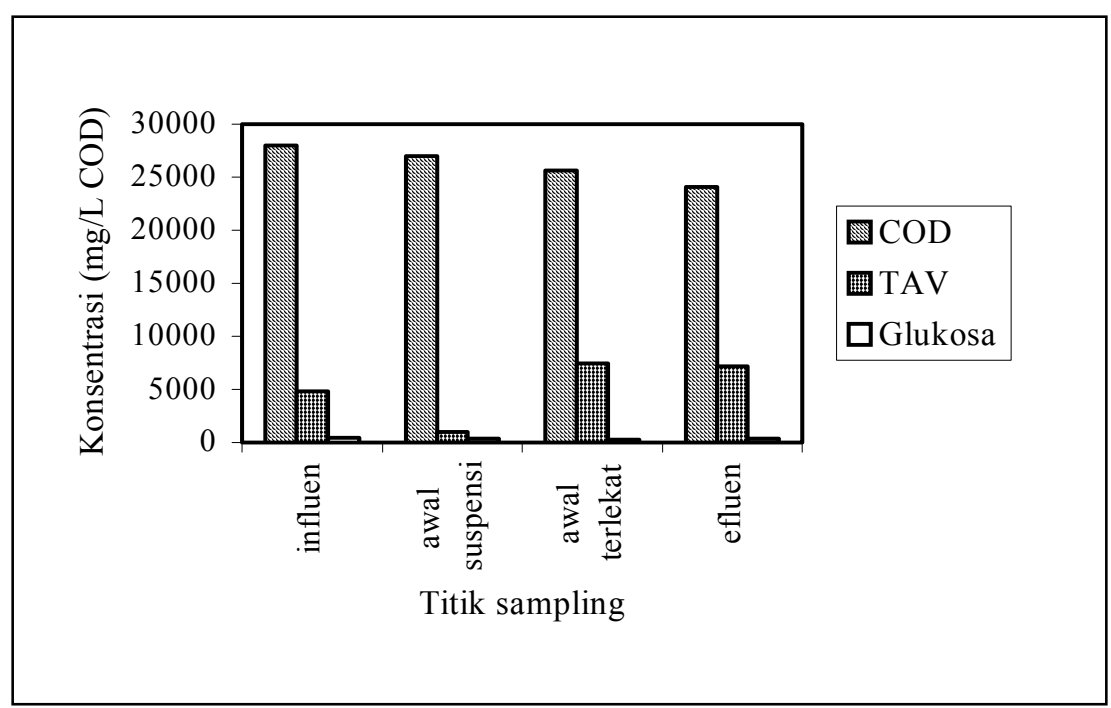

Gambar 4. Konsentrasi COD, TAV dan Glukosa dalam bioreaktor hibrid pada konsentrasi $30.000 \mathrm{mg} / \mathrm{L} \mathrm{COD}$ 


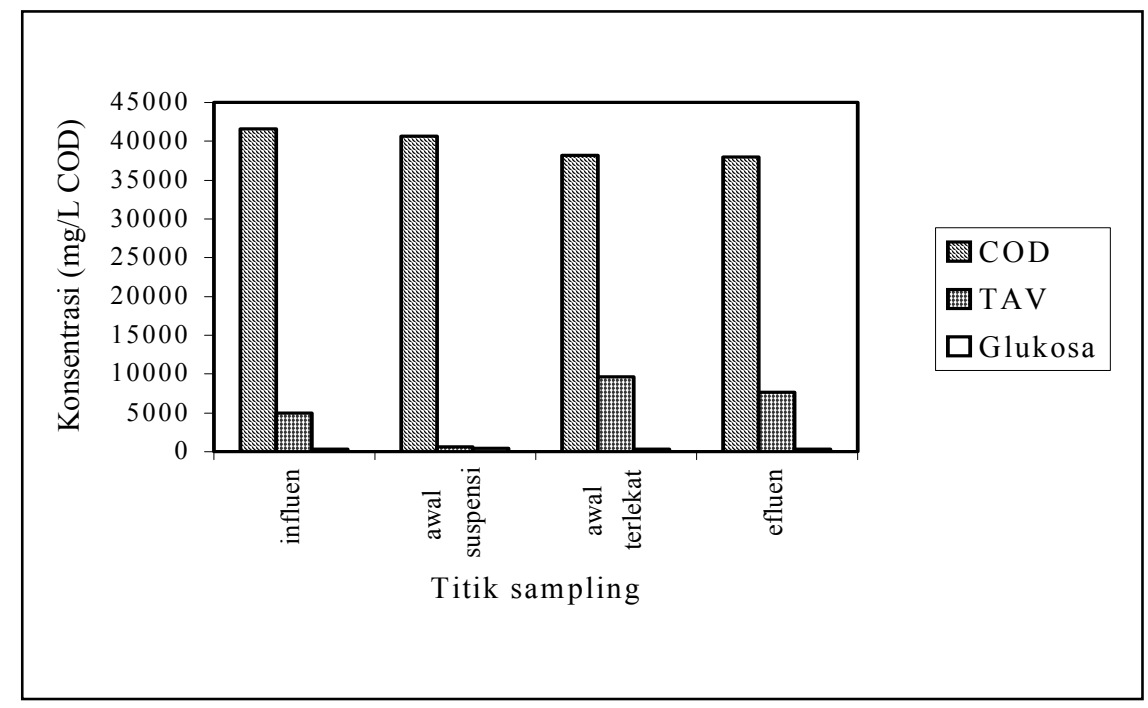

Gambar 5. Konsentrasi COD, TAV dan Glukosa dalam bioreaktor hibrid pada konsentrasi $40.000 \mathrm{mg} / \mathrm{L}$ COD

Ada dua fenomena yang terjadi dalam bioreaktor. Pada konsentrasi 10.000 $\mathrm{mg} / \mathrm{L}$ COD, penurunan nilai COD terbesar pada bagian tersuspensi. Hal ini menunjukkan bahwa pada bagian tersuspensi tidak hanya berlangsung proses asidogenesa, tetapi juga sudah masuk pada tahap metanogenesa. Pada bagian terlekat dapat dikatakan tidak terjadi penyisihan COD. Besar kemungkinan materi organik yang tersisa merupakan materi yang sukar digunakan sebagai substrat oleh biomassa yang ada di dalam reaktor.

Pada konsentrasi 20.000, 30.000 dan 40.000 mg/L COD, penurunan nilai COD yang terjadi relatif tidak terlalu besar. Hal ini mungkin dikarenakan bahwa pada proses fermentasi tidak terjadi penyisihan COD, senyawa organik hanya berubah bentuk ke bentuk senyawa organik lainnya [5]. Oleh karenanya, proses yang berlangsung pada reaktor baik pada bagian tersuspensi maupun terlekat tampaknya masih berupa proses asidogenesa.

Konversi materi organik menjadi bentuk yang lebih sederhana dapat dilihat pada pembentukan TAV. Hasil pengukuran parameter TAV memperlihatkan adanya peningkatan pada bagian tersuspensi yang menunjukkan berlangsungnya proses asidogenesa yang menghasilkan asam-asam lemak. 
Selanjutnya pada bagian terlekat, jumlah TAV akan menurun. Penurunan ini terjadi akibat aktivitas proses metanogenesa yang mengubah produk metabolisme proses asidogensa menjadi gas metan.

Masih adanya TAV pada efluen memperlihatkan bahwa bagian terlekat memiliki keterbatasan dalam menjalankan proses metanogenesa. Pada konsentrasi organik yang lebih besar dari $10.000 \mathrm{mg} / \mathrm{L}$ COD, TAV yang terbentuk pada bagian tersuspensi melebihi $3.000 \mathrm{mg} / \mathrm{L}$ asetat. Akibatnya proses metanogenesa pada bagian terlekat hanya mampu mengubah sekitar $4,5 \%$ sampai $27 \%$ TAV menjadi biogas.

Secara umum, parameter glukosa tidak memperlihatkan suatu fenomena khusus. Kecenderungan yang terjadi adalah pada bagian tersuspensi ada peningkatan jumlah glukosa, yang kemudian diikuti dengan penurunan jumlah glukosa pada bagian terlekat. Proses yang terjadi pada bagian tersuspensi adalah hidrolisis molase menjadi glukosa yang dilanjutkan dengan pembentukan asam-asam lemak dari glukosa tersebut.

Hasil-hasil diatas dapat dibandingkan terhadap proses pengolahan molase konsentrasi sekitar $40.000 \mathrm{mg} / \mathrm{L}$ COD secara anaerob menggunakan reaktor UASB (Upflow Anaerobic Sludge Blanket) dengan volume 100 L. Pada pengolahan tersebut diperoleh efisiensi penyisihan rata-rata $75 \%$ dengan waktu detensi hidrolis 2 sampai 17 hari dan produksi metan rata-rata sebesar $58 \%[6]$.

Guiot dan Berg, 1984 [7] melakukan penelitian dengan reaktor hibrid yaitu dengan mengkombinasikan sludge blanket dengan filter. Sludge blanket pada bagian bawah dengan volum 2/3 dari keseluruhan volum reaktor dan 1/3 volum di atasnya merupakan filter dengan media plastik (Flexiring, Kock Inc. $235 \mathrm{~m}^{2} / \mathrm{m}^{3}$ ). Reaktor ini dioperasikan pada temperatur $27^{\circ} \mathrm{C}$, untuk mengolah air buangan industri gula (2500 mg COD/L) dengan laju pembebanan 5 - $51 \mathrm{gr}$ COD/L. hari, HRT 13 jam, dan dilakukan resirkulasi dengan ratio 5,4. Laju produksi metan 7 vol/vol.hari (STP). Penyisihan (berdasarkan konsentrasi COD efluen terlarut) lebih dari 93\% dengan laju pembebanan 26 gr COD/L.hari. Pada laju pembebanan yang lebih tinggi penyisihan COD menurun dengan cepat.

\section{Pembentukan Gas Metan}

Hubungan antara penyisihan COD dan pembentukan gas metan dalam berbagai variasi konsentrasi organik dapat dilihat pada Gambar 6. Gambar 
tersebut memperlihatkan bahwa peningkatan konsentrasi organik menyebabkan penurunan penyisihan nilai COD dalam air buangan. Penurunan ini disertai pula dengan penurunan produksi gas metan. Untuk waktu detensi hidrolis yang sama, semakin besar konsentrasi organik akan semakin banyak asam volatil yang dihasilkan oleh proses asidogenesa. Kondisi ini menyebabkan populasi bakteri metanogen tidak dapat melangsungkan proses metanogenesa dengan sempurna, sehingga hanya sebagian produk proses asidogenesa yang dikonversi menjadi gas metan. Akibatnya persentase penyisihan COD akan menurun disertai dengan penurunan persentase pembentukan gas $\mathrm{CH}_{4}$. Hal ini sesuai dengan jumlah TAV yang masih terdapat pada efluen air buangan. Data tersebut membuktikan bahwa proses metanogenesa belum berlangsung sempurna.

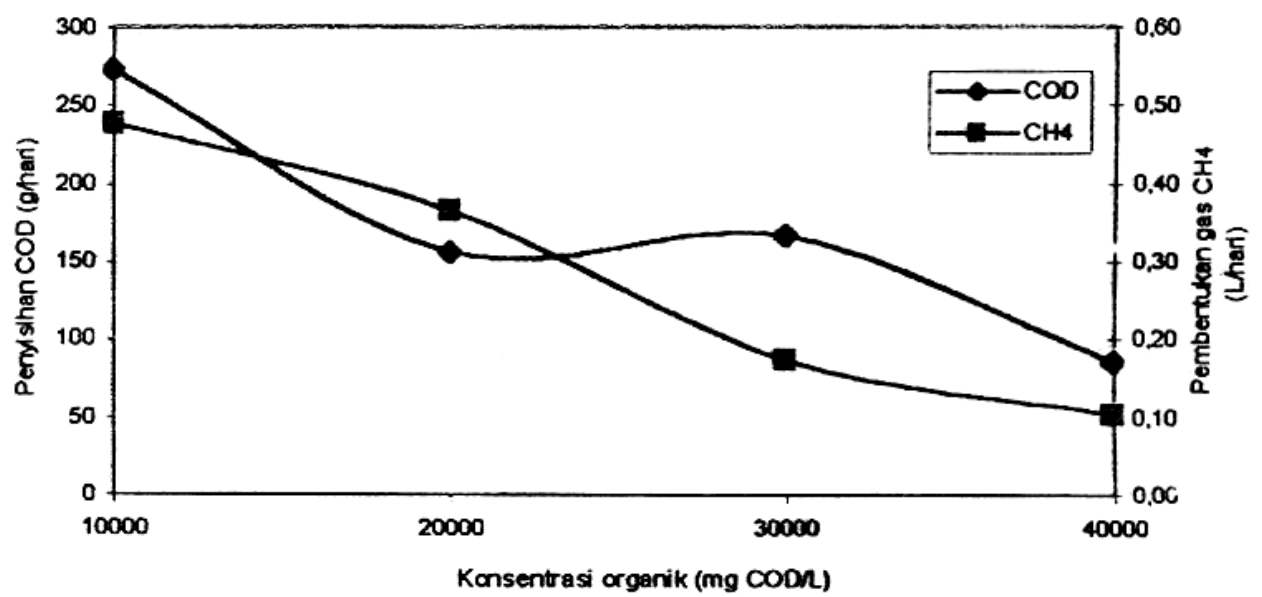

Gambar 6. Pengaruh variasi konsentrasi organik terhadap penyisihan COD dan pembentukan gas metan

Produksi gas metan dalam penelitian ini berkisar antara 0,0017 hingga $0,0023 \mathrm{~L} / \mathrm{g}$ COD yang disisihkan. Secara stoikiometri jumlah gas yang dihasilkan setiap penyisihan 1 gram COD seharusnya adalah 0,34 L [1]. Jumlah gas metan yang dihasilkan dalam pengolahan ini masih jauh dibawah jumlah yang seharusnya diproduksi. 


\section{Koefisien Hasil}

Koefisien hasil merupakan suatu besaran yang menyatakan jumlah penggunaan suatu materi. Dalam pengolahan anaerob ini dihitung koefisien hasil pembentukan asam volatil dan gas metan. Pada variasi konsentrasi organik ternyata makin besar konsentrasi organik maka makin besar produksi asam-asam volatil (Tabel 3). Kondisi ini menyebabkan terjadinya akumulasi asam-asam volatil pada reaktor dan membutuhkan waktu untuk proses metanogenesa yang lebih lama.

\begin{tabular}{|c|c|c|c|c|c|c|c|}
\hline \multirow{2}{*}{$\begin{array}{l}\text { Kons. } \\
\text { (mg/L } \\
\text { COD) }\end{array}$} & \multicolumn{3}{|c|}{$\mathrm{COD}(\mathrm{mg} / \mathrm{L})$} & \multicolumn{3}{|c|}{ TAV (mg/L asetat) } & \multirow{2}{*}{$\begin{array}{c}\mathrm{Y}(\mathrm{mg} \\
\mathrm{TAV} / \mathrm{mg} \\
\mathrm{COD})\end{array}$} \\
\hline & Inlet & Outlet & $\Delta S$ & Inlet & Outlet & $\Delta \mathrm{P}$ & \\
\hline 10.000 & 11.734 & 5.235 & 6.499 & 217 & 817 & 600 & 0,092 \\
\hline 20.000 & 21.458 & 17.747 & 3.711 & 4.133 & 5.017 & 883 & 0.238 \\
\hline 30.000 & 28.021 & 24.064 & 3.957 & 4.483 & 6.717 & 2.233 & 0,564 \\
\hline 40.000 & 41.592 & 39.543 & 2.049 & 4.651 & 7.200 & 2.549 & 1,244 \\
\hline
\end{tabular}

Tabel 3. Koefisien hasil pembentukan asam volatil

Bila tidak dikonversikan menjadi metan, secara stoikiometri, $1 \mathrm{mg}$ COD akan menghasilkan 5,82 mg asetat. Bila dibandingkan dengan hasil pembentukan total asam volatil yang berkisar 0,092 - 1,244 mg asetat/mg COD, hasil pembentukan asam volatil dalam bioreaktor masih sangat rendah.

Pembentukan gas metan merupakan indikasi keberhasilan proses anaerob. Hasil perhitungan koefisien hasil pembentukan gas metan diperlihatkan pada Tabel 4. Produksi gas metan memiliki kaitan dengan proses pembentukan asam volatil. Makin banyak asam volatil yang terbentuk, diperlukan waktu tinggal sel bakteri metan yang lebih lama untuk mengkonsumsi seluruh asam tersebut. Dengan demikian, jika waktu detensi tetap, sedangkan konsentrasi organik dinaikkan, ada kecenderungan terjadinya penurunan pembentukan gas metan. 


\begin{tabular}{|c|c|c|c|c|c|c|}
\hline \multirow{2}{*}{$\begin{array}{c}\text { Kons. } \\
\text { (mg/L } \\
\text { COD) }\end{array}$} & \multicolumn{3}{|c|}{ COD (mg/L) } & \multirow{2}{*}{$\begin{array}{c}\text { COD } \\
\text { tersisih } \\
\text { (g/hari) }\end{array}$} & $\begin{array}{c}\mathrm{CH}_{4} \\
(\mathrm{~L} / \mathrm{hari})\end{array}$ & $\begin{array}{c}\mathrm{Y}\left(\mathrm{L} \mathrm{CH}_{4} /\right. \\
\mathrm{g} \mathrm{COD})\end{array}$ \\
\hline 10.000 & 11.734 & 5.235 & 6.499 & 273 & 0,479 & 0,092 \\
\hline 20.000 & 21.458 & 17.747 & 3.711 & 156 & 0,366 & 0.238 \\
\hline 30.000 & 28.021 & 24.064 & 3.957 & 167 & 0,174 & 0,564 \\
\hline 40.000 & 41.592 & 39.543 & 2.049 & 86 & 0,104 & 1,244 \\
\hline
\end{tabular}

Tabel 4. Koefisien hasil pembentukan gas metan

\section{Kesimpulan}

Proses yang berlangsung dalam bioreaktor hibrid anaerob media batu dengan rasio tinggi bagian tersuspensi terhadap bagian terlekat 1:2 untuk mengolah air buangan dengan konsentrasi organik sebagai molase sampai dengan $40.000 \mathrm{mg} / \mathrm{L}$ COD, masih didominasi oleh proses asidogenesa baik pada bagian tersupensi maupun pada bagian terlekat. Proses metanogenesa terlihat sudah mulai berlangsung namun belum sempurna, bila bioreaktor dioperasikan pada waktu detensi hidrolis sebesar 30 jam. Ada kemungkinan ketidaksempurnaan kinerja bioreaktor ini akibat tingginya kandungan $\mathrm{SO}_{4}{ }^{2}$ dalam air buangan yang dapat menginhibisi proses biodegradasi anaerob.

\section{Rujukan}

1. Leslie Grady dan Henry C. Lim, Biological Wastewater Treatment: Theory and Application, $2^{\text {nd }}$ ed., Marcel Dekker, New York, (1991).

2. R.E. Speece, Anaerobic Biotechnology for Industrial Wastewater, Archase Press, Tennessee, (1996).

3. P. Weiland dan A. Rozzi, The Start-up, Operation and Monitoring of High-rate Anaerobic Treatment System: Discusser's Report, Water Sci. Technol., 24 (8), 257-277, (1991).

4. Malina, Joseph F. dan Frederick G. Pohland, 1992. Design of Anaerobic Processes for the Treatment of Industrial and Municipal Wastes. Technomic Publishing Company Inc. Pennsylvania. 
5. Anthony Gaudy dan Elizabeth Gaudy, Microbiology for Environmental Scientists and Engineers, McGraw Hill, New York, (1980).

6. F. Sanchez Riera, Use of the UASB Reactor for the Anaerobic Treatment of Stillage from Sugar Cane Mollasses, Biotechnol. Bioeng., Vol. XXVII, 1710-1716, (1985).

7. Guiot, S. R. dan Van Den L. Berg., 1985. Performance of an Upflow Anaerobic Reactor Combining a Sludge Blanket and a Filter Treating Sugar Waste. Biotechnology and Bioengineering. Vol. 27. Hal. 800-806. John Wiley \& Sons Inc., 1985. 